\title{
2D Electrical Resistivity Imaging for Delineation of Crystalline Basement Aquifer in Northern Ghana
}

\section{Akwasi Acheampong Aning1*, Charles Kwabena Sarfo1, Patrick Amankwaa Mainoo², Reginald Mensah Noye ${ }^{1}$}

\footnotetext{
${ }^{1}$ Department of Physics, Kwame Nkrumah University of Science and Technology, Kumasi, Ghana

${ }^{2}$ Water Research Institute (WRI), Council for Scientific and Industrial Research (CSIR), Accra, Ghana

Email: *acheamponganing@gmail.com
}

How to cite this paper: Aning, A. A., Sarfo, C. K., Mainoo, P. A., \& Noye, R. M. (2019). 2D Electrical Resistivity Imaging for Delineation of Crystalline Basement Aquifer in Northern Ghana. Journal of Geoscience and Environment Protection, 7, 102115.

https://doi.org/10.4236/gep.2019.712007

Received: November 7, 2019

Accepted: December 14, 2019

Published: December 17, 2019

Copyright $\odot 2019$ by author(s) and Scientific Research Publishing Inc. This work is licensed under the Creative Commons Attribution International License (CC BY 4.0).

http://creativecommons.org/licenses/by/4.0/

\begin{abstract}
Lack of access to potable and adequate water is a major problem for sustainable development in northern Ghana. Developing groundwater resource is the best option for safe, reliable, and cost-efficient water supplies to these dispersed communities. In this study, nine 2D ERI profiles were carried out with the Schlumberger array in eight communities underlain by the crystalline basement rocks in the Bole District of the Savannah Region of Ghana. The aim was to delineate the aquifer zones and select points for groundwater extraction. Nine boreholes were drilled from the selected points. The yield was found to vary from 12 to $180 \mathrm{l} / \mathrm{min}$ with a depth range of 50 to $70 \mathrm{~m}$. The weathered and fractured zones together with the bedrock topography were clearly marked. It is evident that the $2 \mathrm{D}$ electrical resistivity technique is useful tool in determining the availability of groundwater in weathered and fractured crystalline environment.
\end{abstract}

\section{Keywords}

Electrical Resistivity Imaging, Ghana, Crystalline, Aquifer, Mapping

\section{Introduction}

The demand for water for domestic, industrial, and agricultural use the world over continues to increase due to increase in population size. In most developing countries including Ghana, accessing potable water for domestic use for instance is a major challenge, particularly, to rural dwellers and in some instances cities as well. As a result of this challenge, most people source water from streams, 
rivers, dams, and lakes. The irony is that most of these surface water bodies are severely contaminated from agricultural, illegal mining, and other anthropogenic activities. The use of such water poses a major health threat to people thereby affecting their overall contribution to a country's GDP.

Human beings have relied on fresh water since creation for both domestic, industrial, and agricultural purposes. Water indeed is a basic necessity to livelihood. It covers about two-third of land space available in the world (Gleick, 1993).

Groundwater is such an important economic resource, particularly in areas where surface water is scarcely available. Most often large quantities of groundwater are pumped from drilled wells for domestic, agricultural and industrial use. Sometimes, even, in areas where surface water is readily available groundwater is preferred because it is less contaminated. In many occasions' communities sourced water they need from lakes, rivers, or reservoirs, sometimes canals to transport water from far surface sources. Alternatively, communities can draw water from what is stored below the Earth's surface. This resource is called groundwater; the water found below the Earth's surface, occupying the pores space between grains in materials of sediments, and clastic sedimentary rock, and filling fractures, pores or voids that hold groundwater known as aquifer (Plummer et al., 2010). Groundwater sources serve as large sources of freshwater across the world (Pedley \& Howard, 1997). Generally, groundwater is reliable and it is of high quality, so with available and improved technique for drilling and pumping, it is widely found in most areas of the world currently (Giordano \& Villholth, 2007). About half of the human population of the world has relied upon it as their source of drinking water (Anomohanran, 2011).

Ratnakumari et al. (2012) suggested that potential aquifers in weathered/fractured zones are mostly found within the traps or below it. Chandra et al. (2010) explained that the geological discontinuity provides a lot of information about groundwater flow pattern and quartz reefs may provide potential groundwater zone. Muchingami et al. (2012) combined VES and 2D electrical resistivity tomography to evaluate the groundwater potential in the basaltic-greenstone formations. Aizebeokhai et al. (2017) characterized the weathered and fractured areas of the crystalline basement rocks in order to delineate the aquifer using VES and electrical resistivity imaging in Ado-Ekiti, Nigeria.

Surface water resources are in abundance in Ghana but they are unable to meet the demands of the people for domestic, agricultural, and industrial purposes. This is partly as a result of pollution caused by illegal mining or are at some distance from settlements, making it expensive to pump to where it is needed (Kortatsi, 1994). This has made it important to explore groundwater resources as an alternative source to supply potable water to both rural and urban communities for domestic, agricultural, and industrial use. In Ghana groundwater is a source of water supply to about $52 \%$ of rural communities (Gyau-Boakye \& Dapaah-Siakwan, 2000). The search for reliable and potable water particularly for domestic use continues to be a major setback in the country's development. This challenge cuts across the country but it is pronounced in the northern part 
of the country. It is therefore important that this unhealthy situation is eliminated through the provision of accessible and cleaner water particularly in rural and deprived communities where it is prevalent so that poverty can be reduced and a healthy community can be promoted. This can be achieved through the tapping of groundwater resource to provide reliable and potable drinking water.

Weathered and fractured rocks contain most of the aquifers that produce freshwater in Ghana and boreholes yield within the same crystalline rock type vary considerably even when they are very close. According to Ewusi (2006) groundwater in the crystalline basement rocks in western section of the Savannah Region have yields between $135 \mathrm{l} / \mathrm{min}$ and $240 \mathrm{l} / \mathrm{min}$ at a depth ranging between 13 and $59 \mathrm{~m}$. Kyere et al. (2013) found out that in the Bawku West District, the aquifer zones were located between 10 and $40 \mathrm{~m}$ with yields within the range of 10 to $500 \mathrm{l} / \mathrm{min}$ in the Birimian and granitic rock formations. Issah et al. (2018) revealed that in the Tain District, the aquifers are mainly in the weathered and fractured zones with depth in the range of 30 to $60 \mathrm{~m}$ and yields of 15 to $800 \mathrm{l} / \mathrm{min}$. The mean yield and depth of boreholes in the Tarkwaian and Birimian formations are $126 \mathrm{l} / \mathrm{min}$ and $54 \mathrm{~m}$ respectively (Darko \& Krásny, 2007). Groundwater is the preferred choice for the provision of reliable potable water to the rural communities in Ghana due to the dispersed nature of the settlements and closeness of the resource to the populace. The country has a lot of shallow aquifers and as a result less costly to develop as against surface water treatment. Groundwater is better protected from microbial and chemical pollutants and can withstand drought to some extent (Quist et al., 1986; Gyau-Boakye \& DapaahSiakwan, 2000).

Currently, groundwater provides safe drinking water to some communities in the Bole District of the Savannah Region of Ghana. Notwithstanding the wide disparity, most part of the district has access to potable water because of the activities of NGOs but considerable number of boreholes in the Bole District have low yield. Boreholes comprised $79 \%$ of potable water in the district (UNDP, 2011). In some instances, hand-dug wells are used to source groundwater at shallow depths. This is mostly done without any geophysical examination conducted. In order to ensure that there is reliable water supply the subsurface should be properly investigated using appropriate geophysical method so as to site borehole at the right place. One of such geophysical investigation methods is the electrical resistivity method. The choice of this method over others is its ability to delineate effectively potential aquifer zones. Aside the electrical resistivity technique, the electromagnetic technique has been extensively used to prospect for groundwater in the country.

Though a lot of boreholes have been sunk in the crystalline basement rocks of Bole District of the Savannah Region of Ghana, most of the sitings were done without recourse to geophysics and where geophysics was used, it was the point based 1D VES technique that was employed. This conventional 1D technique has not been able to effectively and efficiently produce the desire result, thus, delineating aquifer zones within the subsurface. The non-uniqueness arising from 
problems of equivalence and suppression sometimes introduce errors in the interpretation of 1D VES results and do not give detailed information about subsurface hydro-geological features. There is therefore the need to have a continuous $2 \mathrm{D}$ in-situ electrical resistivity measurement to address this challenge since it gives a thorough interpretation of the subsurface and delineate the features capable of storing groundwater. The focus of this project is to use the $2 \mathrm{D}$ electrical resistivity technique to effectively locate aquifer zones at various depths in the Birimian crystalline basement rocks in the Bole district of the Savannah region of Ghana and select drilling points for groundwater extraction.

\section{Project Site Description}

The Bole District is centered at $9001160.0011 \mathrm{~N}$ and 2028159.9911 W. The entire Savannah Region including Bole District lies within the Tropical Continental or Interior Savannah climatic zone. This climatic zone experiences with a single maximum rainfall season from May and October followed by a prolong dry season (Dickson \& Benneh, 2004). In terms of vegetative cover, the study area lies within the Guinea Savannah belt. According to Dickson \& Benneh (2004), the Guinea Savannah belt, although is the largest vegetative belt in Ghana, the fringes of the adjacent moist semi-deciduous have tendency to turn into Interior Wooded Savannah due to land use and climate change. Annual average temperatures ranged between $26^{\circ} \mathrm{C}$ and $27^{\circ} \mathrm{C}$ with annual mean rainfall ranging between 1000 and $1200 \mathrm{~mm}$ with relatively high annual evapotranspiration ranging between 1600 and $1650 \mathrm{~mm}$.

The project area is mainly underlain by three main geological formations namely; Birimian Supergroup, which covers $70 \%$ of the area, Voltaian Supergroup, also covers $26 \%$, and $4 \%$ been Tamnean (Figure 1). The Birimian Supergroup is associated with granitoid gneiss with some local diorite. On the other hand, the Voltaian Supergroup underlying the area is predominantly mudstone, siltstone and intercalations of sandstone. The Birimian and the related intrusions dated back to the Paleoproterozoic era (1800 - $2100 \mathrm{Ma}$ ) (Gyau-Boakye \& Dapaah-Siakwan, 2000).

These crystalline rocks, hydrologically, have undergone some degree of structural deformation resulting in the creation of cracks or fractures, thereby leading to the creation of secondary porosity that enhances groundwater development and accumulation. It is in these zones where secondary porosity has occurred where aquifer can be located (Gyau-Boakye \& Dapaah-Siakwan, 2000). The two main aquifers in the area are the weathered zone or 'regolith' which develops on the crystalline basement rocks and the fracture zones within the bedrock.

These aquifers are not extensive and could be delineated with appropriate geophysical studies. A nationwide hydrological assessment conducted in various geological settings indicated that borehole drilled in the various aquifer systems in the Birimian Supergroup have the potential to result in boreholes with yields ranging between 0.41 and $9 \mathrm{~m}^{3} / \mathrm{h}$ (Gyau-Boakye \& Dapaah-Siakwan, 2000). 


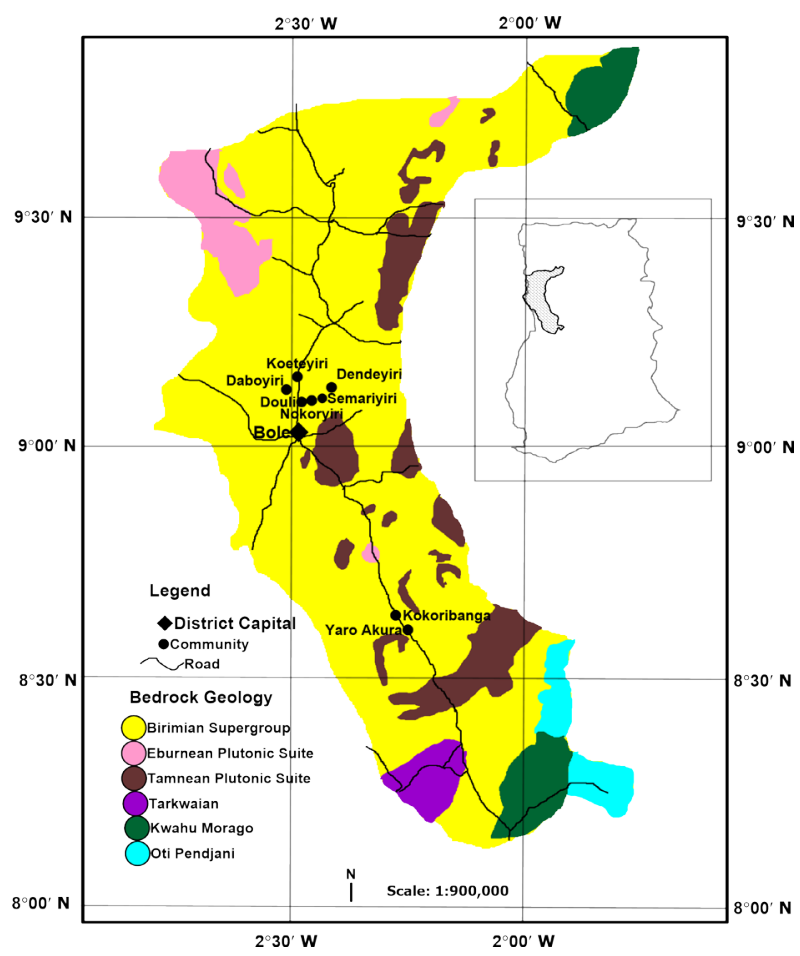

Figure 1. Geological Map of the Bole District showing the study communities.

\section{Materials and Methods}

\subsection{Desktop Study and Preliminary Data Analysis}

In order to have insight to the prevailing hydrogeological conditions in and around the study area, the study commenced by scouting for available groundwater data from previously drilling campaigns. The search span across aerial photographs, geological maps, hydrogeological maps, consultancy reports of previous groundwater resources development within the catchment of the study area as well as databases. The essence of the data gathering and analysis was to gather some information to serve as baseline to inform planning and understanding of the hydrogeological framework of the area under investigations. Critical relevant information gathered include amongst several other types of geophysical methods that had been used in borehole drilling site selection, success rates, drill depths, borehole yields, aquifer transmissivity, hydraulic conductivity, specific capacity and sustainability of established boreholes.

\subsection{Resistivity Method}

Among the geophysical methods that can be used for prospecting for underground resources of economic importance including groundwater are magnetic, resistivity, seismic, gravity, etc. (Parasnis, 2012). Of all the geophysical techniques the electrical methods have shown to be the appropriate techniques for groundwater exploration. The two major techniques employed in electrical methods are the resistivity and electromagnetic methods (Burger et al., 2006). The 
electrical resistivity method can be used to show clearly lateral variation of apparent resistivity (profiling) as well as vertical variation with depth, vertical electrical sounding (VES). The resistivity surveying is extremely valuable and less expensive to use as compared with other geophysical techniques. The problem with VES modeling and interpretation is that a measured sounding curve can be related to many physical models that differ considerably as a result of the principle of equivalence. Thin layers are also suppressed and the suppression rapidly increases with depth. The suppression occurs when the thickness of the layer is not comparable with deposition depth.

The electrical resistivity imaging (ERI) which is an integration of the profiling and VES techniques is the preferred choice lately because it maps complex geology very well. The ERI is a multi-electrode system and the spacing between the electrodes remains the same, but the separation between the potential and the current electrodes varies depending on the electrode configuration. The electrodes are arranged on a line and are connected to a multi-core cable which is connected to a selector and then to the resistivity meter or from the cable to resistivity meter directly (Figure 2 ). The resistivity meter automatically determines the separation and also which electrodes are to be used as current pair and potential pair. The meter measures the apparent resistivities by using a range of different electrode separations and midpoints (Figure 3). It is important to ensure that the electrodes are firm on the ground for high quality data.

In recent times appropriate geophysical methods have been relied upon for the investigation of the subsurface for potential aquifer zones with various degree of success. The resistivity method can be used to determine more accurately depths to bedrock, map graves, fracture zones which are capable of storing groundwater and preferential groundwater flow pathways (Aning et al., 2013a, 2013b; Knödel et al., 2007; Andrews et al., 2013; Nero et al., 2016). The ERI has been used to prospect for groundwater in all the major geologic formations in Ghana (Sikah et al., 2016; Issah et al., 2018).

The multi-electrode ABEM Lund Imaging System was used with the Schlumberger array to acquire nine electrical resistivity images within the crystalline basement rocks of the Bole District. The ERIs had a minimum electrode spacing of $10 \mathrm{~m}$ and a profile length of $400 \mathrm{~m}$. The electrode resistance test was run first before the measurements were taken to ensure that all the electrodes were connected and where the electrode test failed water had to be poured under those electrodes and also hammered deeper to ensure they pass the electrode test. Depths and data points of a typical Schlumberger array is presented in Figure 4.

The field data, which is downloaded from the equipment was analyzed using the RES2DINVx64 software. The software supports the execution of the least-squares method based on a quasi-Newton optimization technique (Loke \& Barker, 1996; Loke, 2019). As part of the quality assurance, the field data to be analyzed is first assessed using the edit tool of RES2DINV to map out bad datum points before the analysis. This is to ensure that outliers (high and low resistivity values are eliminated). These outliers have high tendency to skew the analysis 


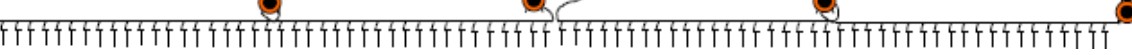

Fiure 2. Typical field arrangement for 2D Apparent Resistivity survey.

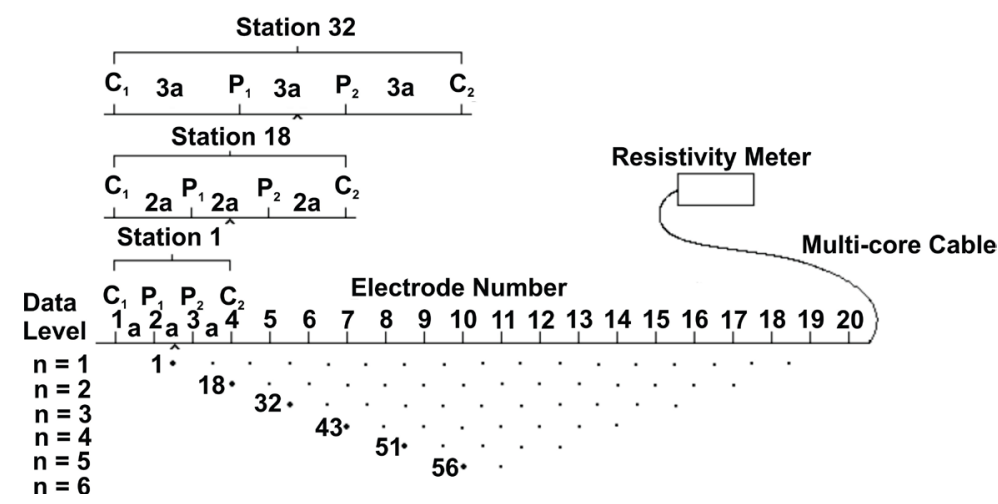

Figure 3. Example of the measurement sequence for building up a resistivity pseudo-section.

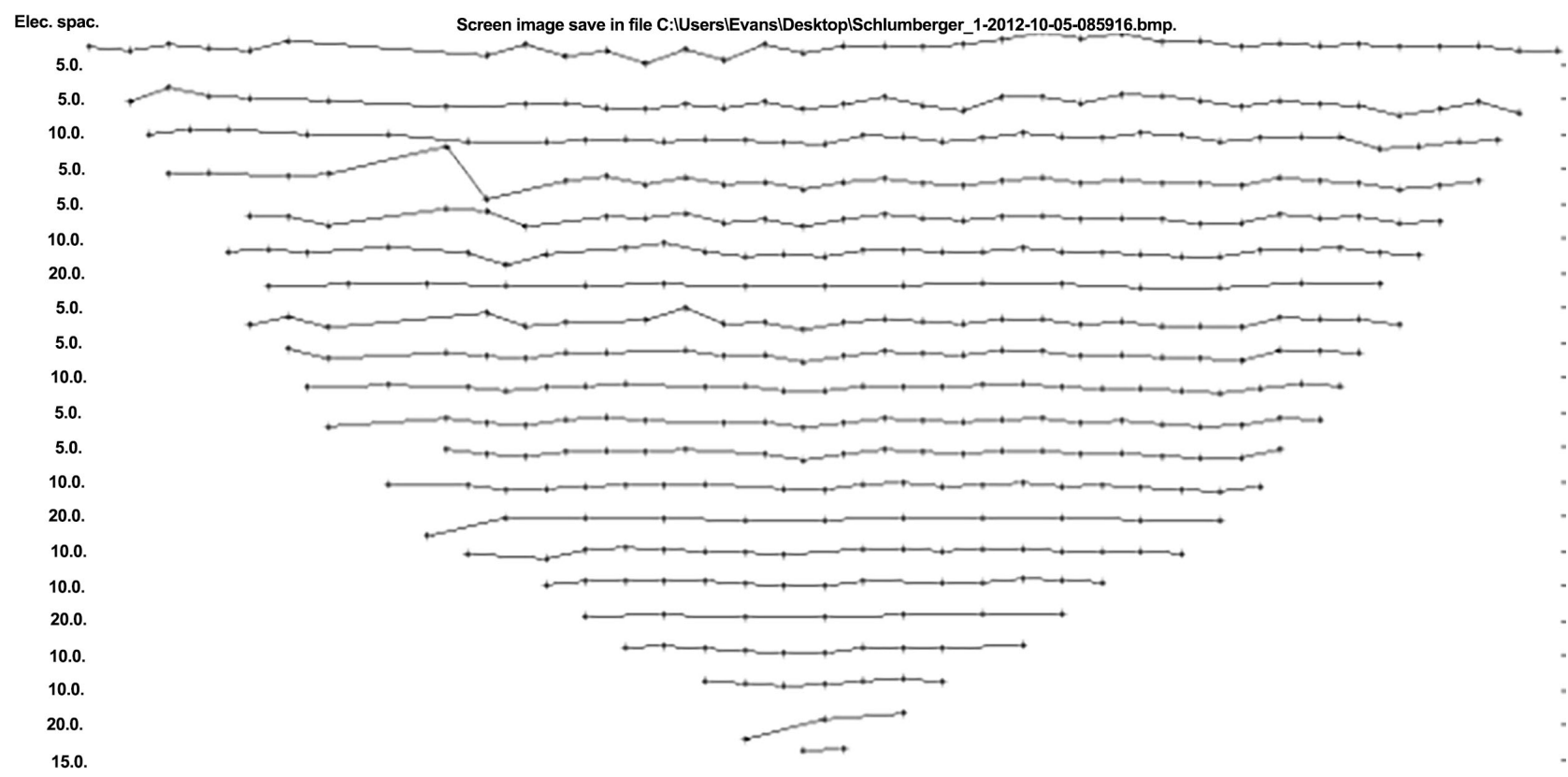

+ Measured data + Removed data

Figure 4. Typical data points in the pseudo-sections of Schlumberger electrode configuration.

to the wrong direction and that affect the apparent resistivity pseudo sections to be generated. Bad data points could be attributed to several factors including failures of relays during readings, poor electrode contact due to dryness of soil, shorting across cables due to extremely wet grounds. The damping factor was set between 1.0 and 3.0 depending on the noise level. During the inversion of the field data the RES2DINV determines the appropriate $2 \mathrm{D}$ apparent resistivity pseudo-section for each of the resistivity survey (Dahlin, 1996; Griffiths \& Barker, 1993; Loke \& Barker, 1996). The apparent resistivity values calculated by the 
RES2DINV are based on a finite-difference modelling subroutine whiles a nonlinear smoothness-constrained least-squares optimization technique used to calculate the resistivity of the model blocks (Groot-Hedlin \& Constable, 1990). The data were topographically corrected.

Zones that are of low resistivity are generally anomalies, that could be fractured/weathered zone with mineralization or groundwater. Clay also has lower resistivity values than other formations which could result in unsuccessful test holes or may produce marginal groundwater.

\section{Results and Discussions}

Figure 5(a) shows 2D electrical resistivity image at Semariyiri. The weathered upper layer (overburden) has a thickness of about $20 \mathrm{~m}$ with resistivity less than $600 \Omega \mathrm{m}$. The bedrock dips towards the end of the profile from $180 \mathrm{~m}$. Within this portion aquifer could be trapped because of the level of weathering that has taken place. No obvious fracture zone was delineated on this profile. The point $290 \mathrm{~m}$ on the profile line was selected for drilling because the weathered zone is very deep at this point and groundwater is predominant in deep weathered zones (Ewusi, 2006). The drilling was done to a depth of $55 \mathrm{~m}$ where substantial amount of groundwater was intercepted. Drill yield was $40 \mathrm{l} / \mathrm{min}$.

The model at Figure 5(b) is the resistivity image at Koeteyiri. The weathered overburden has a lower resistivity less than $220 \Omega \mathrm{m}$ and has a depth of about 30 $\mathrm{m}$ from the surface along the profile. The bedrock rises to the surface between 40 and $60 \mathrm{~m}$ and between 290 and $300 \mathrm{~m}$ from the start of the profile. However, beyond the $260 \mathrm{~m}$ mark on the profile the low resistivity extends into the weathered part of the bedrock. The bedrock dips sharply after $300 \mathrm{~m}$ and the point $310 \mathrm{~m}$ beneath the profile line was selected and drilled to a depth of $60 \mathrm{~m}$. This point was chosen because the weathered bedrock extends deeper and the increased thickness of the overburden here makes this point ideal for groundwater storage (Ewusi, 2006). Drill yield was $12 \mathrm{l} / \mathrm{min}$.

The overburden at Denderiyi as shown in the model image of Figure 5(c) has a low resistivity less than $300 \Omega \mathrm{m}$ down to a depth of about $20 \mathrm{~m}$. There is a slight bulging at mid-point of the profile. There are no visible fractures on this profile. The bedrock is weathered from the beginning of the profile to about 140 $\mathrm{m}$. The distance point $100 \mathrm{~m}$ on the profile line was drilled because that point is less resistive as compared with the other point. Drilling was done to a depth of $50 \mathrm{~m}$ where aquifer was intercepted in the low resistive zone. The yield was 60 $1 / \mathrm{min}$.

The model for Daboyiri profile 1 (Figure 6(a)) clearly shows an overburden with resistivity less than $100 \Omega \mathrm{m}$ and a fairly level bedrock at a depth of about 20 $\mathrm{m}$ with protrusions at $145 \mathrm{~m}$ and between 180 and $190 \mathrm{~m}$. The point selected for drilling was $80 \mathrm{~m}$ from beginning of the profile as a result of the thickness of the regolith at this point. Drilling was done to a depth of $50 \mathrm{~m}$ where aquifer was intercepted and this depth is consistent with aquifer depth in the northern part of Ghana (Gyau-Boakye \& Dapaah-Siakwan, 2000) and drill yield was 60 1/min. 

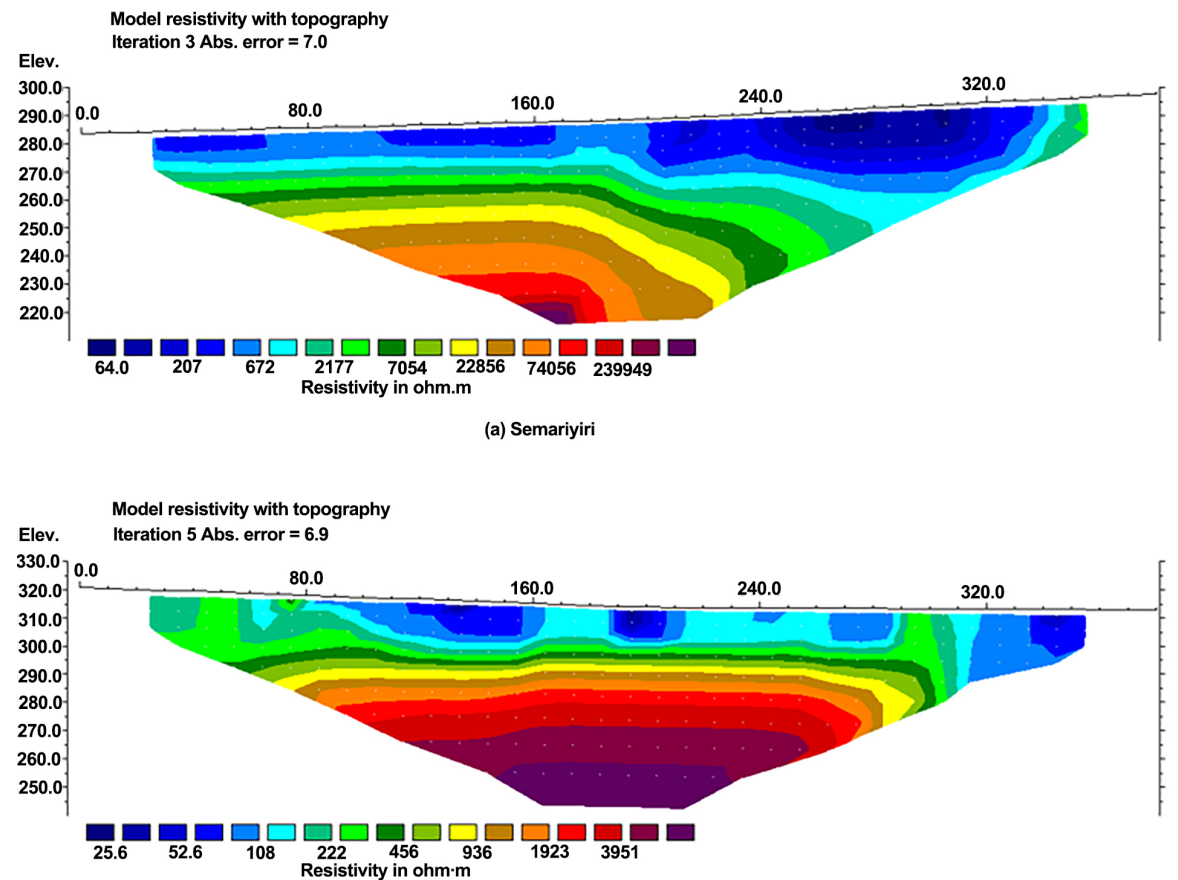

(b) Koeteyiri

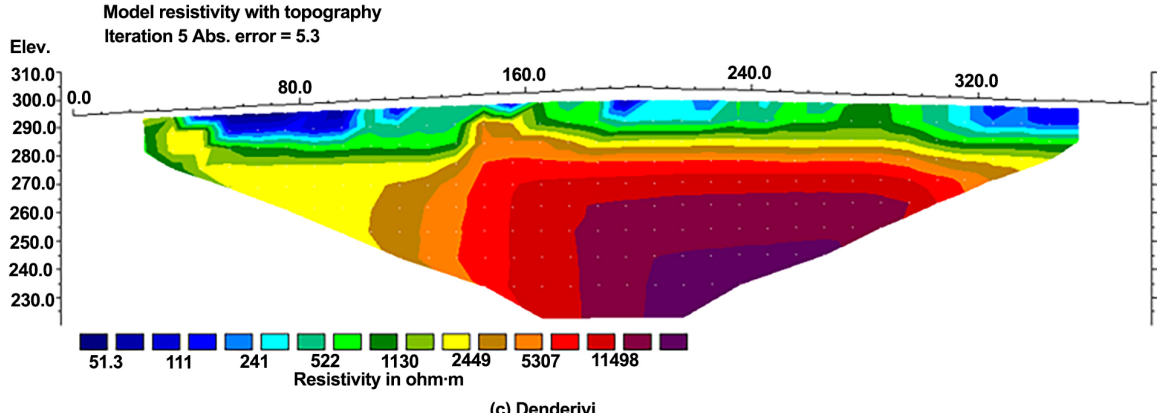

Figure 5. 2D electrical resistivity tomography models of Semariyiri, Koeteyiri and Denderiyi communities in the Bole District, Ghana.

The electrical resistivity model of the second profile at Daboyiri (Figure 6(b)) shows that the resistivity of the weathered upper layer (overburden) is less than $300 \Omega \mathrm{m}$ which is within a depth of about $10 \mathrm{~m}$ from the surface. The bedrock dips slightly away from the first electrode in the direction of the slope. The bedrock climbs to the surface between 120 and $140 \mathrm{~m}$ and between 210 and $220 \mathrm{~m}$. The degree of weathering increases from the starting point towards the end. The distance $280 \mathrm{~m}$ on the profile line was drilled. This point was chosen because it is the thickest weathered layer on the profile (Ewusi, 2006). Drilling was done to a depth of $70 \mathrm{~m}$ where water was struck and drilling yield was as low as $18 \mathrm{l} / \mathrm{min}$.

Figure 6(c) shows the subsurface model of the Douli profile. The upper layer or the overburden has a low resistivity less than $150 \Omega \mathrm{m}$ which is along the entire length of the profile down to a depth of about $20 \mathrm{~m}$. The degree of weathering of the bedrock decreases as you move away from the first electrode. The distance $80 \mathrm{~m}$ on the profile line was selected for drilling due to the thickness of the 

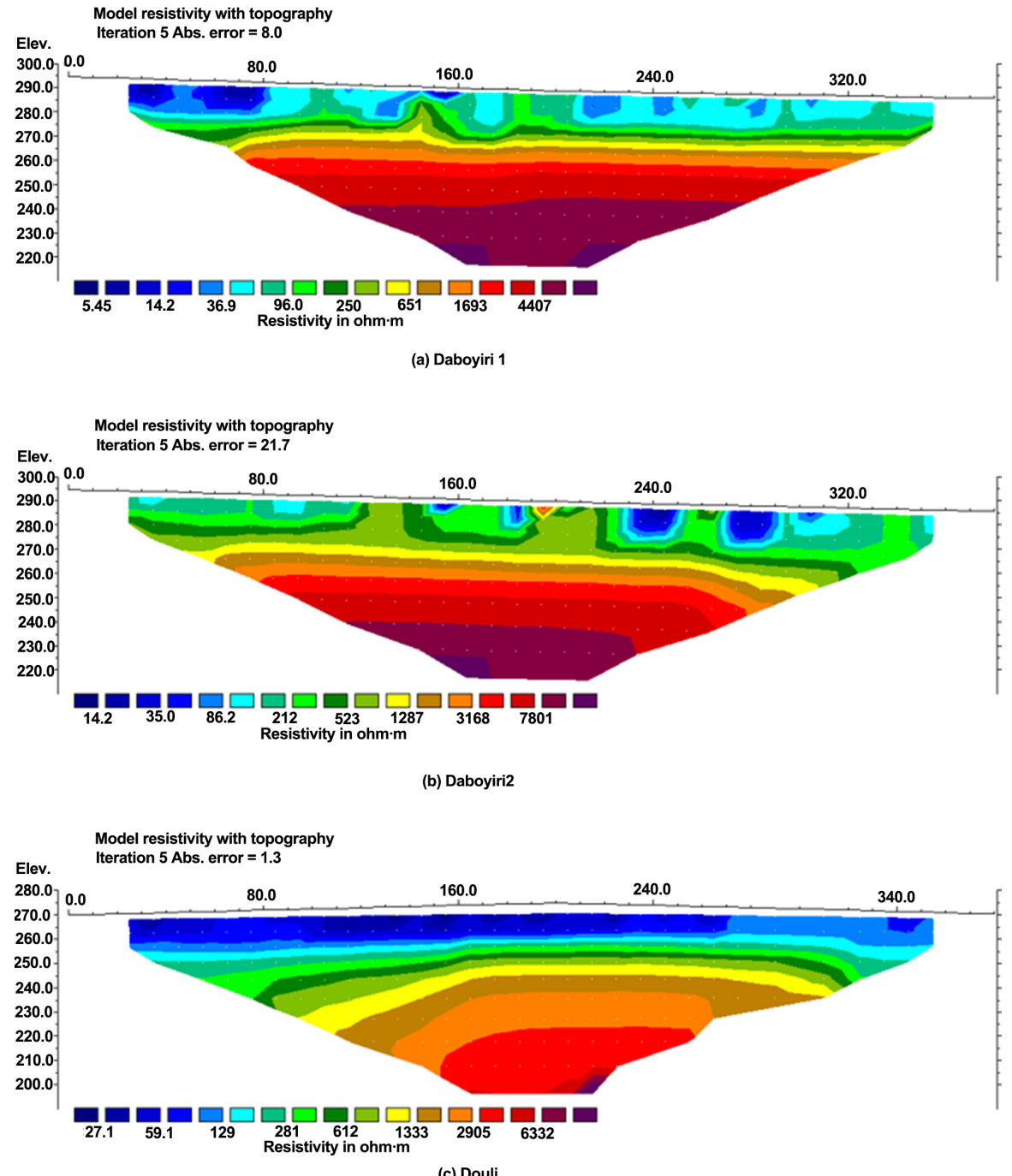

Figure 6. 2D electrical resistivity tomography models of Daboyiri profile 1, Daboyiri profile 2 and Douli communities in the Bole District, Ghana.

weathered bedrock at this portion of the traverse which could serve as a good reservoir for groundwater storage (Barker, 2007). The drilling was done to a depth of $60 \mathrm{~m}$ where water was struck. Drill yield was $120 \mathrm{l} / \mathrm{min}$.

The Kokoribanga electrical resistivity image (Figure 7(a)) has revealed that the thickness of the weathered bedrock with resistivity less than $300 \Omega \mathrm{m}$ increases from about $15 \mathrm{~m}$ from the start of the model to about $25 \mathrm{~m}$ at a distance of $190 \mathrm{~m}$ where the bedrock rises to the surface. The point where the bedrock approaches the surface coincides with the base of the fairly slopping profile and this point was selected and drilled to a depth of $50 \mathrm{~m}$. The yield was $50 \mathrm{l} / \mathrm{min}$.

The $2 \mathrm{D}$ resistivity model at Nokoryiri (Figure $7(\mathrm{~b})$ ) indicates that the overburden has a resistivity lower than $400 \Omega \mathrm{m}$. The bedrock has a variable topography with overburden thickness of about $10 \mathrm{~m}$ in most part of the profile but greater than $20 \mathrm{~m}$ from $320 \mathrm{~m}$ onwards and over $40 \mathrm{~m}$ from start of the profile to $100 \mathrm{~m}$. The bedrock rose to the surface at distance points $225 \mathrm{~m}$ and between 

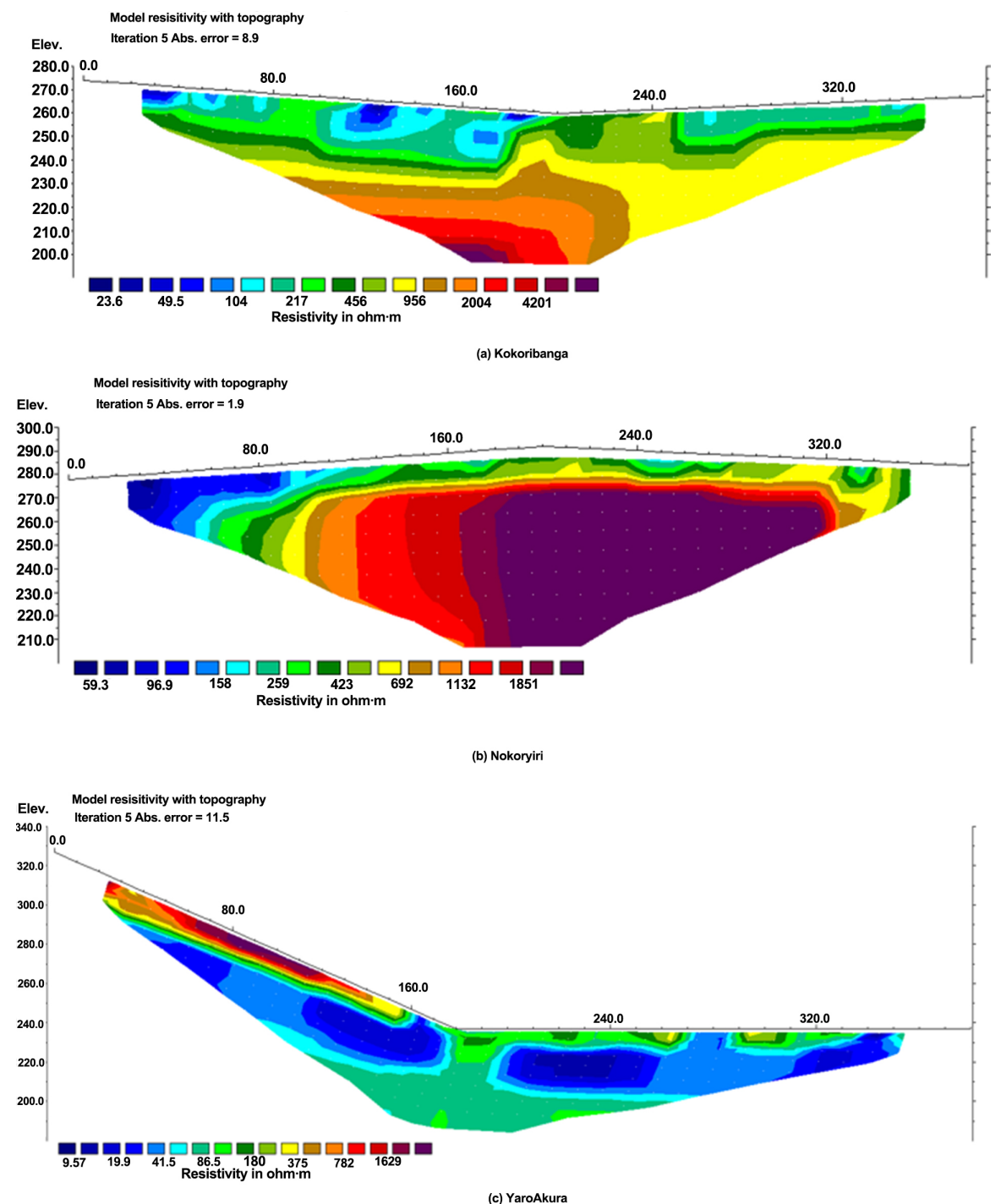

Figure 7. 2D electrical resistivity tomography models of Kokoribanga, Nokoryiri and Yaro Akura communities in the Bole District, Ghana.

310 and $325 \mathrm{~m}$. The distance $80 \mathrm{~m}$ on the profile line was selected and drilled to a depth of $50 \mathrm{~m}$ and drill yield was $150 \mathrm{l} / \mathrm{min}$. This point was chosen owing to the low resistivity (Noye et al., 2017; Kayode et al., 2016) and the thickness of the weathered bedrock (Ewusi, 2006; Jayeoba \& Oladunjoye, 2015).

The steep nature of the Yaro Akura model (Figure 7(c)) suggest that the bottom of the slope will be less resistive because all running water is collected at the bottom of the slope. The high resistive top red colored zone on the left side of the profile up to about $140 \mathrm{~m}$ with thickness of about $10 \mathrm{~m}$ is an impression of the bedrock. Below this resistive region is a low resistivity belt which is as a result of weathering and fracturing effect. The weathering effect can clearly be seen as low resistivity zone on the right side of the model. The point $190 \mathrm{~m}$ which is at the base of the slope was selected for drilling because the aquifer zones on both sides of this point can easily seep into the borehole at this point. Drilling 
was done to a depth of $70 \mathrm{~m}$ and drill yield was $180 \mathrm{l} / \mathrm{min}$.

\section{Conclusion}

The electrical resistivity imaging (ERI) has provided a detailed electrical resistivity distribution and this has led to the delineation of the subsurface features and a better understanding of the geology of the Bole District. The use of the ERI was useful in deciphering potential aquifer zones and selecting drilling points for the extraction of groundwater. The electrical resistivity models produced by the inverse modeling of the apparent resistivity data indicated the thickness of the overburden, the nature of the bedrock surface among others.

The borehole depth ranges between 50 and $70 \mathrm{~m}$ and the borehole yields vary between a low of $12 \mathrm{l} / \mathrm{min}$ to a high of $180 \mathrm{l} / \mathrm{min}$. The overburden thickness ranges from 10 to $30 \mathrm{~m}$ in some parts of the study area and in some communities, the bedrock rises to the surface. Some of the borehole yields were low but can satisfy the water requirement of these small communities. The aquifers in the study area are the weathered basement of the crystalline rocks.

The results obtained from this study show that ERI technique can be used effectively in discovering aquifer zones for groundwater supply because it provides accurate and reliable way of describing the subsurface.

\section{Acknowledgements}

The research was supported by Department of Physics of Kwame Nkrumah University of Science and Technology (KNUST), Kumasi-Ghana and Water Research Institute (WRI) of the Council for Scientific and Industrial Research (CSIR), Accra-Ghana. We wish to thank the Bole District Assembly for their support.

\section{Conflicts of Interest}

The authors declare no conflicts of interest regarding the publication of this paper.

\section{References}

Aizebeokhai, P., Ogungbade, O., \& Oyeyemi, K. (2017). Integrating VES and 2D ERI for Near-Surface Characterization in a Crystalline Basement Terrain. In SEG Technical Program Expanded Abstracts 2017 (pp. 5401-5406). Tulsa, OK: Society of Exploration Geophysicists. https://doi.org/10.1190/segam2017-17587956.1

Andrews, N. D., Aning, A. A., Danuor, S. K., \& Noye, R. M. (2013). Geophysical Investigations at the Proposed Site of the KNUST Teaching Hospital Building Using 2D and 3D Resistivity Imaging Techniques. International Research Journal of Geology and Mining, 3, 113-123.

Aning, A. A., Tucholka, P., \& Danuor, S. K. (2013a). 2D Electrical Resistivity Tomography (ERT) Survey Using the Multi-Electrode Gradient Array at the Bosumtwi Impact Crater, Ghana. Journal of Environment and Earth Science, 3, 12-16.

Aning, A. A., Tucholka, P., \& Danuor, S. K. (2013b). The Bosumtwi Meteorite Impact 
Crater, Ghana: New Results on the Impact Direction of the Meteorite from 2D Electrical Resistivity Tomography (ERT) Survey. International Research Journal of Geology and Mining, 3, 147-157.

Anomohanran, O. (2011). Determination of Groundwater Potential in Asaba, Nigeria Using Surface Geoelectric Sounding. International Journal of Physical Sciences, 6, 7651-7656.

Barker, R. D. (2007). Electrical Resistivity Methods for Borehole Siting in Hardrock Region. In Groundwater (pp. 26-60). Berlin: Springer. https://doi.org/10.1007/978-1-4020-5729-8_2

Burger, H. R., Sheehan, A. F., \& Jones, C. H. (2006). Introduction to Applied Geophysics: Exploring the Shallow Subsurface. New York: WW Norton.

Chandra, S., Dewandel, B., Dutta, S., \& Ahmed, S. (2010). Geophysical Model of Geological Discontinuities in a Granitic Aquifer: Analyzing Small Scale Variability of Electrical Resistivity for Groundwater Occurrences. Journal of Applied Geophysics, 71, 137-148. https://doi.org/10.1016/j.jappgeo.2010.06.003

Dahlin, T. (1996). 2D Resistivity Surveying for Environmental and Engineering Applications. First Break, 14, 275-283. https://doi.org/10.3997/1365-2397.1996014

Darko, P. K., \& Krásny, J. (2007). Regional Transmissivity Distribution and Groundwater Potential in Hard Rock of Ghana. In Groundwater in Fractured Rocks (pp. 125-136). Boca Raton, FL: CRC Press. https://doi.org/10.1201/9780203945650.ch6

Dickson, K. B., \& Benneh, G. (2004). A New Geography of Ghana.

Ewusi, A. (2006). Groundwater Exploration and Management Using Geophysics: Northern Region of Ghana.

Giordano, M., \& Villholth, K. G. (2007). The Agricultural Groundwater Revolution: Opportunities and Threats to Development (Volume 3). Wallingford: CABI. https://doi.org/10.1079/9781845931728.0000

Gleick, P. H. (1993). Water in Crisis: A Guide to the Worlds Fresh Water Resources.

Griffiths, D., \& Barker, R. (1993). Two-Dimensional Resistivity Imaging and Modelling in Areas of Complex Geology. Journal of Applied Geophysics, 29, 211-226. https://doi.org/10.1016/0926-9851(93)90005-J

Groot-Hedlin, C., \& Constable, S. (1990). Occam's Inversion to Generate Smooth, Two-Dimensional Models from Magnetotelluric Data. Geophysics, 55, 1613-1624. https://doi.org/10.1190/1.1442813

Gyau-Boakye, P., \& Dapaah-Siakwan, S. (2000). Groundwater as Source of Rural Water Supply in Ghana. Journal of Applied Science and Technology, 5, 77-86.

Issah, M. M., Aning, A. A., Noye, R. M., \& Mainoo, P. A. (2018). Prospecting for Groundwater Using the Continuous Vertical Electrical Sounding Method. European Scientific Journal, 14, 67-85. https://doi.org/10.19044/esj.2018.v14n3p67

Jayeoba, A., \& Oladunjoye, M. A. (2015). 2-D Electrical Resistivity Tomography for Groundwater Exploration in Hard Rock Terrain. International Journal of Science and Technology, 4, 156-163.

Kayode, J., Adelusi, A., Nawawi, M., Bawallah, M., \& Olowolafe, T. (2016). Geo-Electrical Investigation of Near Surface Conductive Structures Suitable for Groundwater Accumulation in a Resistive Crystalline Basement Environment: A Case Study of Isuada, Southwestern Nigeria. Journal of African Earth Sciences, 119, 289-302. https://doi.org/10.1016/j.jafrearsci.2016.04.009

Knödel, K., Lange, G., \& Voigt, H.-J. (2007). Environmental Geology: Handbook of Field Methods and Case Studies. Berlin: Springer Science \& Business Media. 
https://doi.org/10.1007/978-3-540-74671-3

Kortatsi, B. (1994). Groundwater Utilization in Ghana. In Proceedings of the Helsinki Conference on Future Groundwater Resources at Risk (No. 222, pp. 149-156). Wallingford: International Association of Hydrological Sciences.

Kyere, A., Noye, R., \& Menyeh, A. (2013). Prospecting for Groundwater in the Bawku West District of the Upper East Region of Ghana Using the Electromagnetic and Vertical Electrical Sounding Methods. Journal of the Ghana Science Association, 7, 68-78.

Loke, M. H. (2019). Tutorial: 2-D and 3-D Electrical Imaging Survey.

Loke, M. H., \& Barker, R. D. (1996). Rapid Least-Squares Inversion of Apparent Resistivity Pseudosections by a Quasi-Newton Method 1. Geophysical Prospecting, 44, 131-152. https://doi.org/10.1111/j.1365-2478.1996.tb00142.x

Muchingami, I., Hlatywayo, D., Nel, J., \& Chuma, C. (2012). Electrical Resistivity Survey for Groundwater Investigations and Shallow Subsurface Evaluation of the BasalticGreenstone Formation of the Urban Bulawayo Aquifer. Physics and Chemistry of the Earth, Parts A/B/C, 50, 44-51. https://doi.org/10.1016/j.pce.2012.08.014

Nero, C., Aning, A. A., Danuor, S. K., \& Noye, R. M. (2016). Delineation of Graves Using Electrical Resistivity Tomography. Journal of Applied Geophysics, 126, 138-147. https://doi.org/10.1016/j.jappgeo.2016.01.012

Noye, R. M., Fofie, F. B., Nartey, S. T., \& Mensah, E. K. (2017). Locating Aquifers in Crystalline Granitic Rock Using Electrical Resistivity Technique in the Sissala East District of Ghana. Journal of African Earth Sciences, 7, 68-78.

Parasnis, D. S. (2012). Principles of Applied Geophysics. Berlin: Springer Science and Business Media.

Pedley, S., \& Howard, G. (1997). The Public Health Implications of Microbiological Contamination of Groundwater. Quarterly Journal of Engineering Geology and Hydrogeology, 30, 179-188. https://doi.org/10.1144/GSL.QJEGH.1997.030.P2.10

Plummer, C. C., Carlson, D. H., \& Hammersley, L. (2010). Physical Geology (13th ed.). New York: McGraw Hill.

Quist, L., Bannerman, R., \& Owusu, S. (1986). Groundwater in Rural Water Supply in Ghana. In Groundwater in Rural Water Supply (p. 26). Report of the West African Sub-Regional Workshop, Accra, 20-24 October 1986.

Ratnakumari, Y., Rai, S., Thiagarajan, S., \& Kumar, D. (2012). 2D Electrical Resistivity Imaging for Delineation of Deeper Aquifers in a Part of the Chandrabhaga River Basin, Nagpur District, Maharashtra, India. Current Science (Bangalore), 102, 61-69.

Sikah, J. N., Aning, A. A., Danuor, S. K., Manu, E., \& Okrah, C. (2016). Groundwater Exploration Using 1D and 2D Electrical Resistivity Methods. Journal of Environment and Earth Science, 6, 55-63.

UNDP (2011). Bole District Assembly Human Development Report 2011. 